\title{
Islamic Tourism in Covid-19 and Hahslm with Turbulence Economic
}

\author{
Roikhan MA \\ \{roikhan.ma@uinjkt.ac.id\} \\ UIN Jakarta
}

\begin{abstract}
Sharia-based tourism differentiates in the concepts presented by sharia provisions. Both conventional and Islamic conceptions of tourism reflect the relationship with nature through the use of the Hahslm theory. This theory also looks at knowledge with an Islamic perspective which is based on the Al-Qur'an that tourism is allowed with useful purposes such as taddabur, given the position of humans as servants. This study aims to examine the relationship of tourism to the economy and its impact during the Covid-19 pandemic. The quantitative analysis approach is the research tool used by researchers. This methodology shows a study theory that uses evidence in the form of numbers or, in other words, by obtaining pre-existing hypotheses. With studies by previous researchers, it has been shown that tourism, through foreign exchange, can improve the economy. The tourism sector weakened during the Covid-19 pandemic however, as the activity for traveling is reduced, affecting the decline in foreign exchange, contributing to a decline in the Indonesian economy.
\end{abstract}

Keywords: Tourism; Islam; Covid-19; Economy; Hahslm.

\section{Introduction}

Tourism is a rapidly developing sector as a source of economic income. The tourism industry will contribute to economic development. The flow of visitors to a tourist destination has provided local people with welfare in wealth and health. The growth of tourism in Indonesia is very high, since Indonesia is very rich in flora and fauna, and the size of the impact varies between regions or between countries.

Moreover, through tourism, tourists can be introduced to the natural resources found in the sea, mountains, and air. These attract locals, as well as international tourists, which further develop urban prosperity. Apart from economic benefits, tourism creates links between communities, locally and externally. This relationship is created during tourism visits due to social interactions between people. Therefore, Indonesian people, whose majority are Muslim, must see the tourism sector as a potential new market niche by combining the concept of tourism with Islamic values, Islamic tourism can be the answer to this [1]. 
Islamic hospitality is a popular segment of the world tourism industry. Islamic tourism activities have become an important foreign exchange earner for many Islamic countries, especially those that provide facilities for Muslim tourists. The difference between the definition of a hotel that is by sharia and conventional hotels is that a sharia-based hotel must have prayer facilities in the room, a halal restaurant, a sahur and iftar buffet in the month of Ramadan, a spa, gym, lounge, and separate sauna for male and female guests, separate prayer rooms for men and women, separate pools for families (public), private pools for women, and separate seating facilities for male and female guests [2]. The main obstacle facing SCH (ShariaCompliant Hotels) is removing its entry international or local hotel classification; to compete with other non-Islamic hotels; and include special requirements adapted to international hotel classifications [3].

In the world of tourism, Islamic tourism is a new concept. Islamic tourism, halal-friendly tourist destinations, halal tourism, Muslim-friendly tourist destinations, or halal lifestyle are some other terms that have similar meanings. Sharia tourism has a broader meaning than Islamic tourism. Sharia tourism contains a broader concept that does not conflict with all aspects of Islamic tourism.

Although the concept of sharia tourism has evolved in line with the needs and needs of Muslim tourists, the additional services offered are also beneficial for nonMuslims. Most tourists are also looking for clean and hygienic hotels, food, and other things. And when they travel with sharia tourism hospitality, they will also have a good experience. Islamic tourism must offer an attractive concept that can be identified. Hotels need to be more innovative with a balanced forum for lifestyle use. Another suggestion is to host more 'Muslim Friendly Services and Hospitality' conferences and seminars to raise awareness among all countries [4]. In Indonesia, there is a reciprocal causality relationship between economic growth and tourism, namely tourism growth and mutually beneficial economic growth [5].

The tourism industry, in particular, has an important potential for the world's total Gross Domestic Product (GDP) [6], where one indicator of economic growth is Gross Domestic Product (GDP). Therefore, in Indonesia, the tourism sector is predicted to have a great opportunity to become a contributor to state revenue which in turn can increase economic development and thus improve the welfare of the community.

Tourist visits are at least directly related to work, in which if the number of tourist visits increases, it has the potential to increase employment since tourist visits can 
increase employment. However, when there are high-level jobs, tourism must be followed by high purchasing power.

Hahslm is a theory based on an Islamic perspective that discusses science. When linked with Hahslm's theory, conventional and sharia tourism concepts reflect the environmental relationships, where it is better to have a purpose when traveling to do muhasabah on your own and to be grateful for the favors bestowed by Allah SWT. Thus the enjoyment obtained from tourism is not only physical but also spiritual.

When it comes to tourism, it is consumption. The hahslm theory-which refers to an Islamic perspective or viewpoint-explains the existence of consumption as referring to the hijaiyah letter, namely sin lam mim [7]. The meaning of sin lam mim in consumption here is that people who consume need the money and people need to work to make money. So according to Islamic teachings, this means that there is a need for expenditure when consumers want to consume. There are two forms of consumer spending in Islam, the first is shopping that is done to meet the needs of the world. The second is the expenses incurred in the hereafter to seek happiness. Therefore, if these two forms of tourism can be achieved by striving for goodwill, and to also get the joy given by God to humans in the world through tourism.

Until now, it can be said that the conventional and sharia tourism sector is the second-largest source of foreign-exchange contribution in Indonesia. However, the 2019 pandemic coronavirus disease (Covid-19) affected everything including the tourism sector, which felt the first impact of the Covid-19 outbreak. In the tourism sector, sluggishness occurred just before the existence of positive Covid-19 patients in Indonesia is reported. This is further aggravated by the existence of instructions for maintaining distance (physical distance), and the suggestion of only doing activities at home.

The emergence of coronavirus has had important effects around the world. Some people are afraid to mingle especially with the Chinese population because of the threat of this virus. European visitors have canceled their off-road plans. This fear has an impact on the tourism industry at home and abroad. It has affected a significant part of the economy of the country [8].

The existence of Covid-19 "forced" the government to work hard to find the best solution for its economy, especially for the tourism sector, which has recently had very little to no transactions. In this case, however, the tourism sector is "required" to think hard on how to fulfill their economy, including traders who are 
normally selling in tourist attractions. With the temporary closing of tourist attractions by the government, these attractions can no longer be visited by tourists.

With the presence of tourism, many good things are felt as a result of the development of facilities and infrastructure to increase tourism, such as an increase in the economy. However, the tourism industry suffered economic constraints when the coronavirus pandemic occurred. Many hotel industry business owners and tour guides are now experiencing a sharp decline as a result of booking cancellations or lack of bookings. The tourism sector, which is engaged in tourism services and tourism support services, is experiencing a shortage of jobs due to closures by state regulations [9]. Thus, this makes the income of the people in the tourism sector decline.

\subsection{Problems}

Referring to the introduction described, both conventional and sharia-based tourism have questions that the Indonesian economy needs to address. The presence of the 2019 coronavirus disease pandemic (Covid-19) did, however, cause the economy to decline. First, some questions will be discussed from the introduction

1. Why do modern tourism and the idea of sharia affect the economy in Indonesia?

2. What effect can tourism have on the Indonesian economy?

3. How about the use of Hahslm theory to tourism?

4. Following the Covid-19 pandemic and the decline of tourism sector income, how is Indonesia's connection to the economy?

\subsection{Purpose}

This study aims to answer the questions present in the problem

1. Analyze the impact of traditional tourism and the sharia ideology on Indonesia's economy.

2. Analyze how tourism can impact the Indonesian economy itself.

3. Use the Hahslm Theory to analyze the existence of tourism.

4. Analyzing the Indonesian economy's condition or relationship when revenue in the tourism sector declined after the Covid-19 pandemic.

\subsection{Benefits}

By using the theory of hahslm about the nature of the benefits obtained from tourism physically and morally, this study is useful to find out how Islam views tourism itself. And also seeing how the relationship between tourism and the 
economy will be useful to see the prospects for tourism in the Indonesian economy itself. Furthermore, this research is also useful to see the impact of the 2019 coronavirus disease pandemic (Covid-19) on tourism, which will have an economic impact.

\section{$2 \quad$ Literature Review}

\subsection{Tourism}

Tourism is a variety of tourism activities, according to Law No. 10 of 2009 in Article 1 point 3, which is sponsored by various facilities and services provided by the community, businessmen, government, and local governments. Article 14 also explains that the tourism business covers various industries, including tourism transportation facilities, hotel insurance, food and beverage services, entertainment and recreation, organization of meetings, promotional trips, conferences and exhibitions, spas, etc. [10]. The tourism business is a business that aims to provide tourism facilities or the provision or promotion of tourism goods and attractions, tourism product businesses, and other related businesses. The tourism industry is an organizational structure that is involved in the development, manufacture, and marketing of service products to meet the needs of tourists [11]. Therefore it can be concluded that tourism is an activity carried out by a person or group of people to travel to visit a place organized by the tourism business or the tourism industry.

\subsection{Sharia Based Tourism}

Sharia-based tourism is an operation that is funded by the various community, entrepreneurial, government, and regional service facilities and meets the sharia requirements [12]. Along with the relatively common growth of the tourism sector, the idea of sharia tourism is now becoming a trend in the creation of a tourismbased economy in various locations. This definition includes customs based on Islamic values, as well as lifestyle, so that the goods offered are halal [13]. Therefore, from this understanding, it can be concluded that sharia-based tourism is an activity that uses the facilities provided for traveling to other places, which is of course by the provisions of the sharia to gain happiness in the world and blessings from Allah SWT.

Islamic tourism has become a trend in the world and tourists are sure to be attracted by this new concept. Local governments continue to build and plan services and facilities according to Islamic rules [14]. It can be said that sharia 
tourism is a combination where tourists get a double result, namely looking for physical satisfaction and also as worship (inwardly) in practice if tourism is used to empower themselves and reinforce belief in Allah SWT. Sharia-based tourism can also complement existing conventional tourism. Sharia tourism can be an option for Muslim tourists who want to enjoy nature and also have spiritual needs to get happiness. Not only Muslim tourists can enjoy sharia-based tourism, but also nonMuslim tourists can enjoy it.

\subsection{Hahslm Theory}

Theory $\mathrm{H}$ is a translation of the basic words of Islam itself. The methods can be developed in life, such as the development of knowledge related to humanity and God [7].

According to this theory, the $\mathrm{H}$ theory has two meanings the following.

1. A complete set / whole system / integrated part will consist of three main elements, namely primary (creator/intermediary), secondary (creation/receiver), tertiary (worship/transmitter), which can be charged positively or negatively.

2. Such three elements will fulfill the assertion that secondary must do tertiary under primary (the man was made for worship by God).

When "A" reflects the relationship with the community analogously in everyday life, "h" reflects the relationship with fellow human beings, "S" reflects the relationship with yourself, "L" reflects the relation with the environment, and $M$ reflects the ethical relationship [7]. From the explanation above, it can be concluded that the hahslm theory is a theory based on an Islamic perspective that discusses science. Therefore, any conventional science that exists, everything that is based on sharia can be seen from an Islamic perspective and Islamic values.

\subsection{Economy (Development and Growth)}

Developing the economy is an effort or process to bring change for the better. The process of economic development involves various changes in various social, political, economic, and cultural aspects. So development is an absolute requirement for the survival of a country. In contrast to economic growth, we also equate population growth with human development. High economic growth is a development goal [15]. Thus it can be concluded that a country's economy can grow and develop if a country changes different aspects of the economy for the better, and if a country grows in its economy, that country can develop its economy.

There are several factors for the success of a country's development, namely: 
1. Natural resources, human resources, and science and technology

Natural resources or SDA (Sumber Daya Alam) are one of the essential aspects of economic production, the development of natural resources is impossible without them. SDA requires trained human resources to support it. The presence of science and technology can complement human resources in mastering natural capital effectively and efficiently.

2. State Politics and Government Systems and Facilities

Politics and government systems can influence the policies to be applied in the market. Government policy also affects the management of existing facilities and infrastructure.

\subsection{Covid-19}

The coronavirus is one of the main pathogens often affecting the human respiratory system with an initial pneumonia diagnosis. Covid-19 is not a super hot spread virus but is more likely to spread because many patients are infected throughout the hospital at different locations [16]. The coronavirus was described as an unexpected causative agent for outbreaks of pneumonia and was later renamed Covid-19 by WHO. Covid-19 is caused by the SARS-CoV-2 beta coronavirus, which affects the lower respiratory tract and presents as pneumonia in humans [17].

\section{$3 \quad$ Methodology}

The research methodology is the action which researchers take in the form of compiling research components so that findings can be easily made about the items being studied. Where a question is investigated whether testing techniques can be used to help researchers come up with a solution. So, every time a researcher conducts research it's necessary to have a facilitating research method.

\subsection{Research Scope}

The purpose of this study is to determine the effect on the economy, especially due to the existence of conventional and sharia-based tourism, further considering its impact on the Indonesian economy when the Covid-19 virus appears. The research carried out is a quantitative research method that collects existing theories and it can be said that this research method is general.

Quantitative research methods can be defined as a research method based on the philosophy of positivism, used to examine a population or sample, collect data using research instruments, analyze quantitative/statistical data to test 
predetermined assumptions [18]. The methodology used relies on exact measurement results when using quantitative analysis methods. Or in other words, quantitative statistical techniques use data in the form of numbers when interpreting a research sample.

\subsection{Sample Determination Method}

The sampling method has different types depending on the research the researcher is going to do. The sampling methods are, in general, probability sampling and nonprobability sampling. But this time, researchers used a nonprobability sampling method. Where this research is not carried out randomly or randomly in the sampling so that the non-probability sampling method in this study is appropriate. Non-probability sampling is a technique that does not provide the same opportunity or opportunity for every element or member of the population to be selected as a sample [19].

Some of the techniques used when the study used a sample research method with nonprobability sampling, and purposive sampling technique was appropriate in this study. Sampling in this study was carried out by purposive sampling, which means that the sampling technique using non-random samples is expected from this technique to respond to research problems. In short, purposive sampling helps to ensure that the sample taken is by the research objectives and will solve the problem later, purposive sampling is used by researchers if a study is carried out which requires certain requirements so that the technique used will fulfill the purpose of conducting a study.

This research includes data on the number of tourists in Indonesia before the Covid-19 virus, data on the number of tourists in Indonesia after the Covid-19 virus pandemic, data on the Indonesian population infected with the Covid-19 virus, data on economic development in Indonesia. Indonesia before the presence of the Covid19 virus from foreign exchange earnings from the tourism sector.

\subsection{Data Collection Method}

Data collection conducted by researchers aims to obtain the information needed to achieve the achievement of research objectives. In research, researchers collect data using the documentation method by collecting information and data. The data collected by researchers was obtained through scientific journals obtained from http://scholar.google.com/ while the data reports are obtained from 
https://www.covid19.go.id, https://databoks.katadata.co.en/, https://bnpb.go.id, Ministry of Tourism and Creative Economy, https://bps.go.id.

In the secondary data collection method, the data obtained indirectly from the object or subject of the study, or it can be said that when the study uses secondary data means the data obtained by the researcher comes from other parties. Because this research did not obtain data collected and processed by the direct researchers. However, this study obtained data from http://scholar.google.com/, https://www.covid19.go.id, https://databoks.katadata.co.id/, https://bnpb.go.id, Ministry of Tourism and Creative Economy, https://bps.go.id.

\subsection{Research Operational Variable}

Research variables are things that are needed by researchers in conducting research, this necessary thing is usually predetermined and conclusions will be obtained from the research variables. Seeing the researcher's title, "The Link Between Conventional Tourism and Sharia and Hahslm with Covid-19 and Economics," the operational variables of the title are obtained by obtaining two variables, namely the independent variable and the dependent variable.

It was obtained from the title given by the researcher

1. Bound Variable (Dependent Variable)

A variable that gives power to the independent variable is the dependent variable or dependent variable. Coronavirus disease 2019 (Covid-19) is the dependent variable in this analysis and is a virus that only appeared in 2019 and has been declared a pandemic.

2. Independent Variable

The Independent variable is a variable that is determined by the dependent variable. In this study, the independent variables are hahslm theory, tourism, both conventional-based tourism and sharia-based tourism, and the economy. Thus, this study examines how tourism with the Hahslm theory is specific to the Indonesian economy, and how the 2019 coronavirus disease (Covid-19) pandemic affects both conventional and sharia-based tourism.

\section{$4 \quad$ Result and Discussion}

Tourism may be said to enjoy the beauty of the universe as a self-reflection. It's not just conventional oriented tourism, there is also tourism focused on the Sharia. The world of tourism continues to grow and always presents something 
new. Islamic tourism is a new phenomenon in the world of tourism. Indonesia has been widely recognized throughout the world for its victory in the "World Halal Travel Summit and Exhibition 2015" as the best halal tourism in the world. Indonesia managed to get three awards at once, including World's Best Family Friendly Hotel, World's Best Halal Honeymoon Destination, and World's Best Halal Travel Destination. This is certainly a great opportunity that makes it easy for the Indonesian State to continue to develop Islamic tourism [20].

The economic development of a nation is related to the welfare of its people. So, when the economic situation of a country is strong, people can claim that the citizens of that country are prosperous. In Indonesia, the tourism sector (both conventional and sharia) plays an important role in national economic growth, because tourism will generate foreign exchange from foreign tourist visits, regional income, regional development, as well as investment and labor and business development. absorption. So, from now on, economic growth will increase. By multiplying the impact of other tourism-related economic sectors, such as hotels, handicrafts, and so on. So, tourism can accelerate economic growth. Also, employment has increased. When viewed from the existing data, that Indonesia has foreign tourists who have both conventional and sharia-based tourism in a number that can improve the economy.

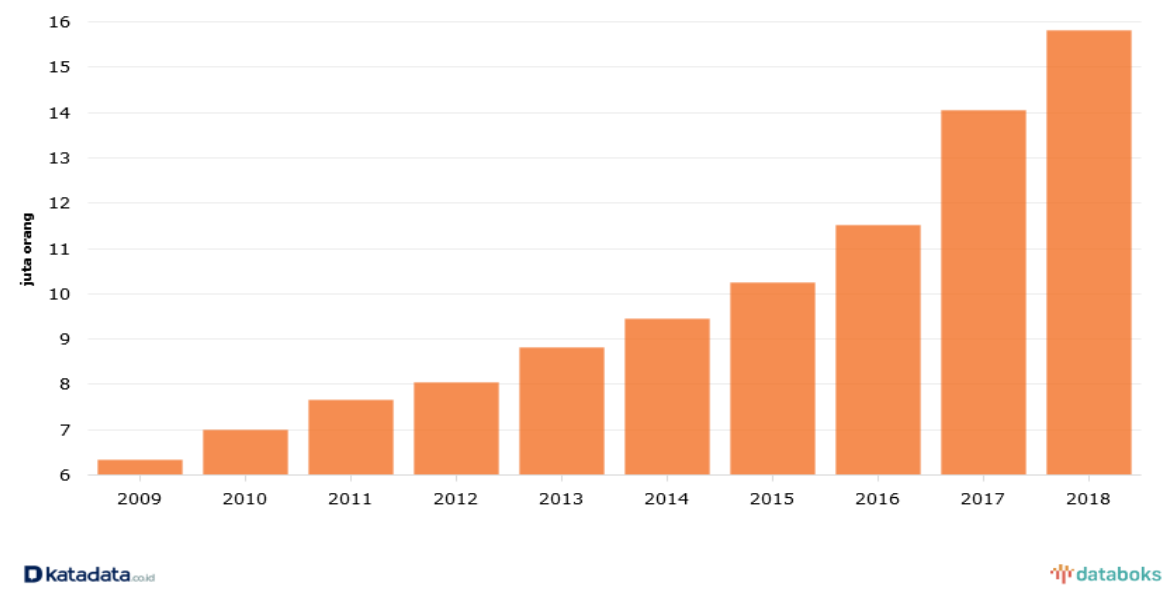

Figure 1. Foreign Tourists Visiting Indonesia. (KataData, 2019a)

In 2014-2018, the average growth of foreign tourists visiting Indonesia reached 14 percent per year. This means that the average growth of foreign tourist 
visits to Indonesia in 2014-2018 was higher than the average growth of foreign tourist visits in 2009-2013 which averaged 9 percent per year. Indonesia has also experienced an increase in the number of domestic or domestic tourists in addition to the arrival of foreign tourists which has always increased significantly. The number of visits has not only increased. The purchasing power of domestic tourists has even increased.

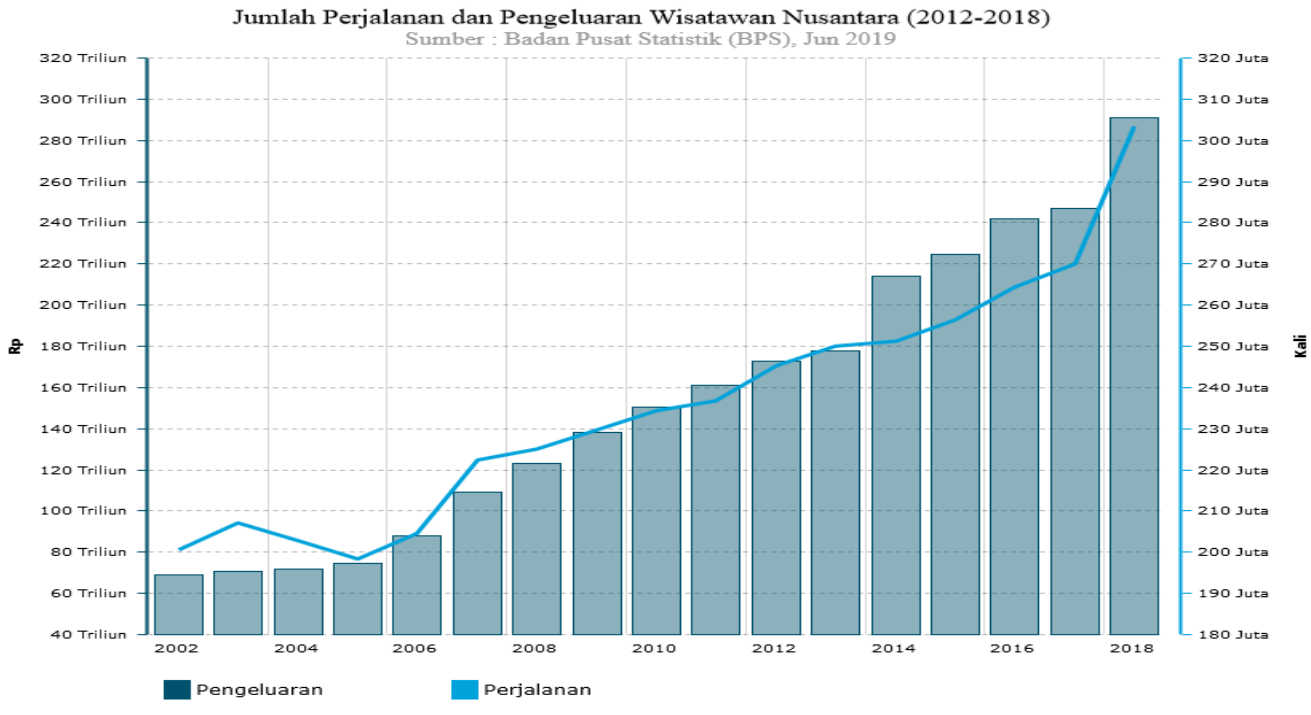

Figure 2. Tourist Trips To The Archipelago.

(KataData, 2019b) 
The number of tourist trips above to the archipelago is a combination of conventional and sharia-based tourism which continues to increase until the end of 2018. This reflects the increasing purchasing power of tourists from the archipelago. The number of trips made by tourists from the archipelago in 2018 was 303.4 million, an increase of 12.37 percent. The expenditure of Indonesian tourists in 2018 shows a figure of IDR 291 trillion, which means that it has grown by 12.89 percent. This indicates that the purchasing power of domestic tourists is increasing. When presented with Hahslm's theory, tourism represents environmental relationships. If you also use the theory of Hahslm which sees knowledge from an Islamic perspective that Allah SWT allows tourism. Not only for the happiness of the world, because of tourism. However, if tourism is expected to generate human gratitude, and can be used to do muhasabah itself.

There are many advantages of tourism (exploring the earth of Allah or rihlah), this is regulated by several arguments in the Qur'an. Including QS. Al-Mulk, QS: 15. Mohamed: 10, QS. Ali 'Imran: QS 137. An-Naml: QS, 69. Luqman, QS: 31. Ar-Rum: 42, and QS. Ar-Rum: -9, QS. And Al-An'am: 11. Each of these theses follows, Allah SWT which means, "Didn't they have traveled through the land and seen how the previous one ended? Allah destroys [everything] over them, and for the disbelievers is something comparable. "(Muhammad's letter: 10)

From this chapter, visiting God's earth (tourism) aims to see the beautiful scenery of the world created by Allah SWT. Where from here we can know so as not to be greedy and continue to do muhasabah by ourselves. In human life in this world, Islam always invites people to travel and do activities to produce goodness in the world and the hereafter. Allah SWT encourages people to travel with them, pay attention to what they see. This means that if it is accompanied by tadabbur, people will get a plus in their rihlah, because tadabbur will remind them of their position as servants of God. So it is not only satisfaction received but also reward or compensation from Allah SWT [21].

What is most needed today in sharia-based tourism is knowledge and understanding of the different cultures that interact with each other in every aspect of everyday life. Tolerance, respect, and sharing with others must be done with sincere understanding and good intentions [22]. Thus, from tourism, Muslim tourists can display an attitude of compassion, reverence, and assistance to other visitors, so that from here they can be a way of preaching to Muslim tourists about a Muslim's positive attitude. 
The growth of the tourism industry in Indonesia, seen from an economic perspective, exceeds the average national economic growth. The tourism sector makes a significant contribution to Indonesia's Gross Domestic Product (GDP) and is the largest contributor to regional income, as regards employment, to the tourism sector as the largest labor contributor [23]. Where it can be said from these factors that the tourism sector contributes to economic growth through foreign exchange earnings. The relationship between international tourist arrivals and foreign exchange earnings from tourism in developed countries has a long-term balance or a balanced relationship, indicating a strong causality between tourism foreign exchange earnings in the long run [24]. Thus, it can be concluded that an increase in tourism will increase the country's foreign exchange earnings, especially the visits of foreign tourists. The economy will improve when foreign exchange rises.

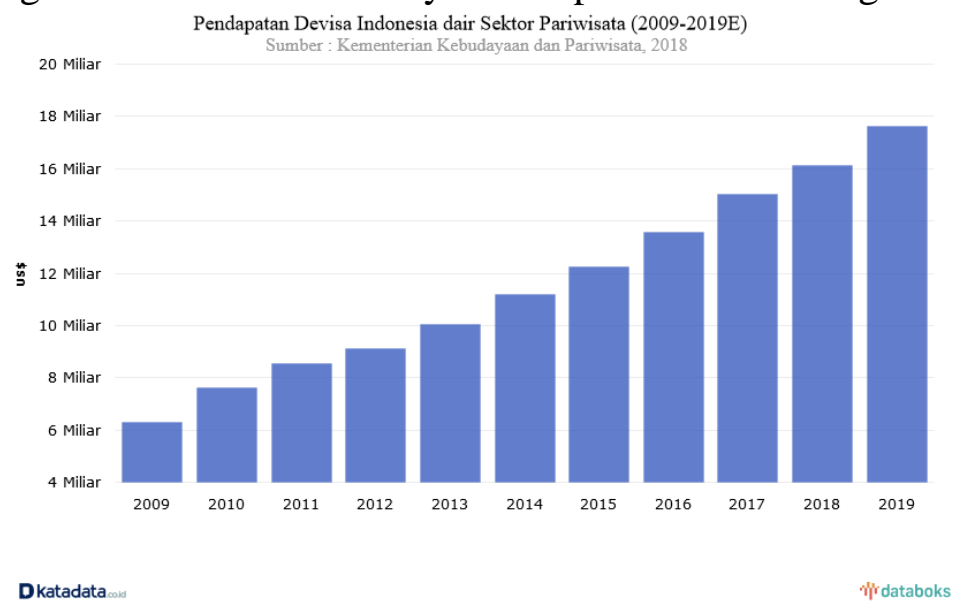

Figure 3. Foreign Exchange. (KataData, 2018)

Based on these data, foreign exchange earnings from the tourism sector reached the US \$ 12.23 billion in 2015 or the equivalent of Rp. 169 trillion. The value of foreign exchange as the largest contributor to Indonesia's foreign exchange ranks fourth in 2015, behind oil and gas, coal, and palm oil. Then, in 2019, tourism foreign exchange revenue is targeted at the US \$20 billion, beating oil and gas exports.

From these data, it can be said that the arrival of foreign tourists to Indonesia has increased. So that the foreign exchange profits increase along with the increase 
in international tourist arrivals. Foreign exchange is one of the tools to improve a country's economy. Where, this shows the country's foreign exchange is increasing along with the increase in foreign tourist visits, and from there the Indonesian economy has also increased. Today, the international population is facing Covid19 pandemic. The Indonesian state has been affected. Some have been infected by the virus until now.

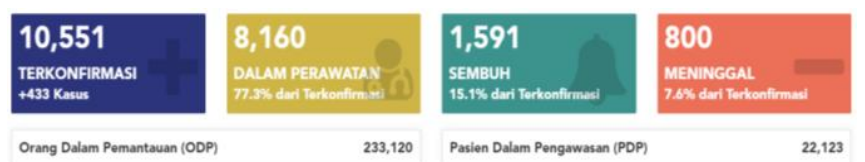

Figure 4. Total Cases Of Indonesian Citizens Who Were Positive For Covid-19.

(Covid19.go.id, 2020)

The total cases of Indonesian citizens who were positive for Covid-19 as of 1 May 2020 reached 10,551. There were 1,591 confirmed cured patients. The patient who died, however, has shown 800 cases. ODP is 233,120 and PDP is 22,123.

Table 1. Daily Covid Media Reports 


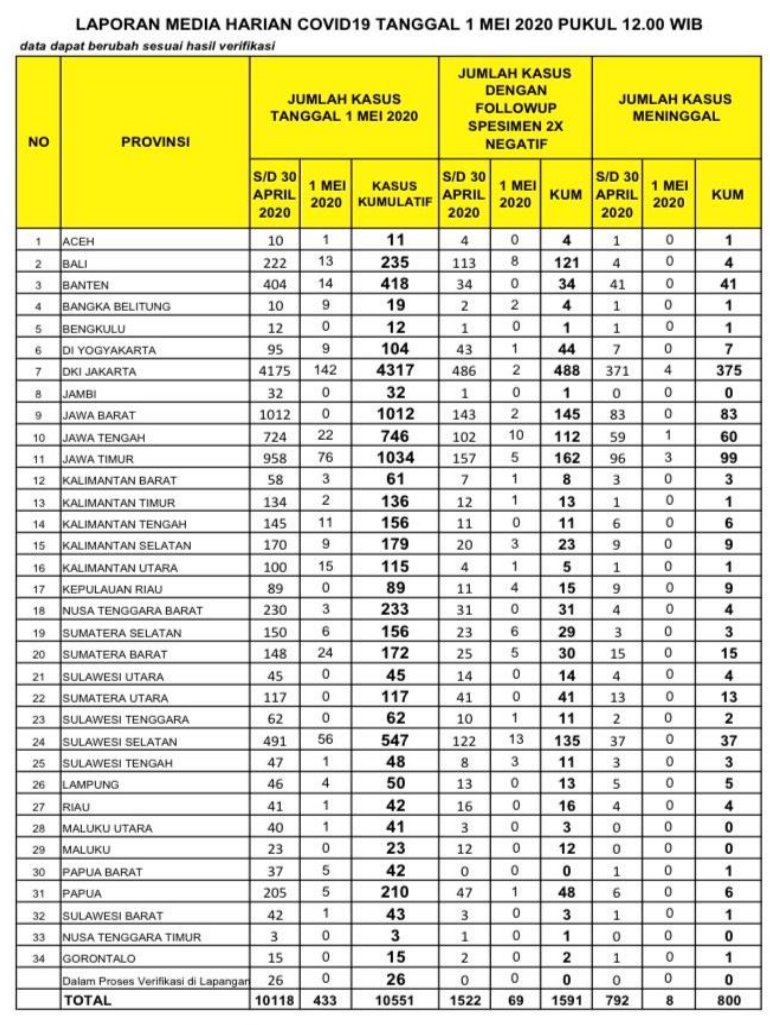

Sumber Data : Kementerian Kesehatan RI

(BNBP, 2020)

The data shows that all provinces in Indonesia are exposed to positive cases of corona as of 1 May 2020 which can be seen in the cumulative case table. The majority of corona positive sufferers in DKI Jakarta Province are 4,317 people. Furthermore, in East Java, there were 1,034 positive cases of corona cases. The coronavirus outbreak does not only concern public health. This also has an impact on the Indonesian economy. Where the virus spreads rapidly. Therefore, to reduce the spread of the coronavirus, the government agreed to limit any activities including economic activities. Government-regulated economic activity restrictions also have an impact on the tourism sector. 
Table 2. The Development Of Foreign Tourist Visits To Indonesia PERKEMBANGAN KỤNJUNGAN WISATAWAN MANCANEGARA KE INDONESIA

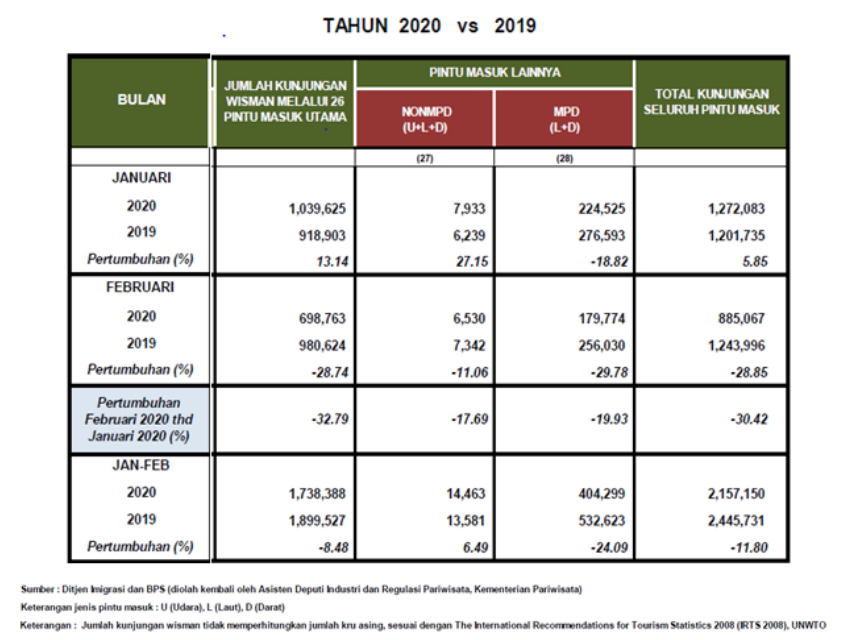

(BPS, 2020)

The government has provided instructions during the coronavirus pandemic to maintain physical distance and recommend activities at home. Because foreigners and Indonesians don't want the virus to attack them. So they don't travel abroad much. In Indonesia alone, the growth of foreign tourist visits has decreased by 30.42 percent in February 2020 compared to January 2020. The decline in growth was also $11.80 \%$ in January-February 2020 compared to January-February 2019. Due to the 2019 coronavirus pandemic. Disease (Covid) -19) decreased tourist arrivals, especially foreign tourists, causing a decrease in foreign exchange reserves. This also had a direct impact on the decline of the Indonesian economy. The data below proves it. 


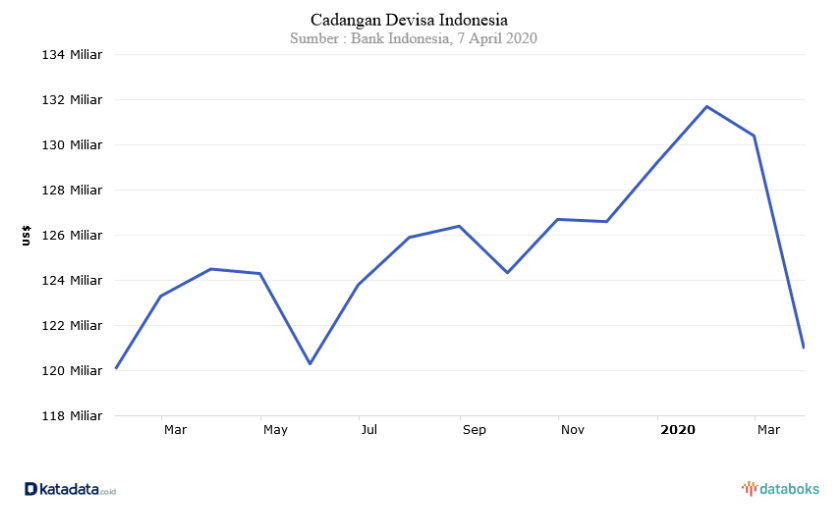

Figure 5. Indonesia's Foreign Exchange.

(KataData, 2020)

In February 2020, foreign exchange reserves reached the US \$ 130.4 billion. However, the figure reached the US \$ 121 billion in March 2020. This means a decrease in foreign exchange reserves of US $\$ 9.4$ billion or 7.2 percent. The decrease in foreign exchange reserves was caused because they were used to pay government debts and maintain the rupiah exchange rate. This is also caused by a decrease in foreign exchange earnings from the tourism sector, namely a decrease in foreign tourist visits.

Where the tourism sector, which has been a contributor to the country's foreign exchange spread through the two eleven oil and gas sectors, has become an important industry or sector that the government can rely on to become the main pillar of national economic development [25]. Tourism visits carried out mainly by foreign tourists thus have a significant impact on the country's foreign exchange earnings. However, when the Covid-19 pandemic occurred, foreign tourist visits to Indonesia decreased. This has an impact on reducing foreign exchange earnings. This causes the Indonesian economy to decline, even though foreign exchange earned from the tourism sector is one of the supporting factors for improving the Indonesian economy. The economic decline due to decreased foreign exchange earnings will also have an impact on the decline in the welfare of the Indonesian people in the future. 


\section{Conclusion}

Indonesia has tourist attractions to visit with many choices and beautiful tourist attractions. So it's no wonder that many foreign and domestic tourists visit Indonesia to see the charm of Indonesia's beauty. Not only Indonesia itself offers traditional travel-related services. However, Indonesia also offers sharia-based tourism, and it is felt not only by Muslim tourists but also by non-Muslim tourists. Tourism is also allowed in Islam in Hahslm theory which views knowledge from an Islamic point of view even though it can bring benefits, and this has been regulated in the Koran.

After the researchers conducted research using quantitative methods, it was seen that tourist visits, especially foreign tourists, had a relationship with the country's foreign exchange, both those who carried out traditional and sharia-based tourism. This relationship shows that the country's foreign exchange has also increased when the number of tourist arrivals, especially foreign tourists, has increased, which indicates a direct connection. Where tourism can increase the country's foreign exchange income, the economy will be stimulated.

However, currently, the 2019 coronavirus pandemic (Covid-19) has been felt in Indonesia and even the world. Whereas of 1 May 2020, there were 10,551 cases of positive patients affected by the coronavirus, the results of research conducted by researchers using quantitative methods. 1,591 patients are confirmed to have recovered from the coronavirus. However, as many as 800 patients died. ODP is 233,120 and PDP is 22,123, respectively. The province most affected by the coronavirus is in DKI Jakarta where there were 4317 positive cases of corona sufferers. The existence of the 2019 coronavirus disease pandemic (Covid-19) does not only have an impact on the health of the Indonesian public. Even so, the Indonesian economy is experiencing a slowdown in line with the government's efforts to suppress the spread of the coronavirus by issuing orders so that people stay at home and exercise physical distance. And this allows people to experience a decrease in economic transactions. The tourism business also experienced a decline in economic transactions.

The 2019 coronavirus pandemic disease (Covid-19) has made many tourists, especially foreign tourists, for fear of being hit by this pandemic refuse to travel to Indonesia. The number of tourist visits, especially foreign tourists visiting Indonesia, decreased when this pandemic occurred. With the quantitative method, it can be seen that tourist arrivals, especially foreign tourists, decreased by 30.42 
percent in February 2020, when the pandemic showed growth in foreign tourist arrivals. Even though it has only been vulnerable for a month, the decline in international tourist arrivals is very high. This means that it could have an impact on reducing foreign exchange earnings, as evidenced by the decline in foreign exchange reserves from February to March by the US $\$ 9.4$ billion or 7.2 percent.

One of the supporting factors driving the economy is foreign exchange earnings from the tourism sector. This means that the decline in visitors, especially foreign tourists, during this pandemic has an impact on reducing the country's foreign exchange income. This can have an impact on the weakening of the Indonesian economy and consequently will reduce the welfare of the community. 


\section{References}

[1] Widagdyo, K. G. (2015). Analisis Pasar Pariwisata Halal Indonesia. The Journal of Tauhidinomics, 1(1), 73-80.

[2] Karim, M. H. A., Ahmad, R., \& Zainol, N. A. (2017). Differences In Hotel Attributes: Islamic Hotel And Sharia Compliant Hotel In Malaysia. Journal of Global Business and Social Entrepreneurship (GBSE), 1(2), 157-169.

[3] Saad, H. E., ALI, B. N., \& Abdel-Ati, A. M. (2014). Sharia-Compliant Hotels In Egypt : Concept And Challenges Badran Nabil ALI Abdel- aleem Magdy ABDEL-ATI. Advances in Hospitality and Tourism Research (AHTR), 2(1), 1-15.

[4] Chandra, G. R. (2014). Halal Tourism; A New Goldmine For Tourism. International Journal of Business Management \& Research (IJBMR), 4(6), 45-61.

[5] Nizar, M. A. (2015). Tourism Effect on Economic Growth in Indonesia. Munich Personal RePEc Archive (MPRA), 7(65628), 1-25.

[6] Ohlan, R. (2017). The Relationship Between Tourism, Financial Development And Economic Growth In India. Future Business Journal, 3(1), 9-22. https://doi.org/10.1016/j.fbj.2017.01.003

[7] Roikhan. (2016). Teori H sebagai ilmu wahyu dan trats dalam Islam. Jurnal Ushuluddin, 24(1), 103-112.

[8] Hoque, A., Shikha, F. A., Hasanat, M. W., Arif, I., \& Hamid, A. B. A. (2020). The Effect of Coronavirus (COVID-19) in the Tourism Industry in China. Asian Journal of Multidisciplinary Studies, 3(1), 52-58.

[9] Hartman, G., \& Nickerson, N. P. (2020). Tourism-Related Business Owners Speak Out About 2020 COVID-19 Impacts. April, 1-39.

[10] Kemenkeu. (2009). Undang-Undang Republik Indonesia Nomor 10 Tahun 2009 Tentang Kepariwisataan.

[11] Rani, D. P. M. (2014). Pengembangan Potensi Pariwisata Kabupaten Sumenep, Madura, Jawa Timur (Studi Kasus: Pantai Lombang). Jurnal Politik Muda, 3(Desember), 412-421.

[12] Kemenpar. (2012). Kajian Pengembangan Wisata Syariah.

[13] Rahmi, N. (2017). Kajian Ekonomi Pariwisata Syariah Kota Banda Aceh. Jurnal Samudra Ekonomi Dan Bisnis, 8(Januari), 577-589.

[14] Ramadhany, F., \& Ridlwan, A. A. (2018). Implikasi Pariwisata Syariah Terhadap Peningkatan

[15] Baeti, N. (2013). Pengaruh Pengangguran, Pertumbuhan Ekonomi, Dan Pengeluaran Pemerintah Terhadap Pembangunan Manusia Kabupaten/Kota Di Provinsi Jawa Tengah Tahun 2007-2011. Economics Development Analysis Journal, 2(3), 85-98. https://doi.org/10.15294/edaj.v2i3.1984

[16] Rothan, H. A., \& Byrareddy, S. N. (2020). The epidemiology and pathogenesis of coronavirus disease (COVID-19) outbreak. Journal of Autoimmunity, 2, 1-4.

[17] Sohrabi, C., Alsafi, Z., O’Neill, N., \& Khan, M. (2020). World Health Organization declares global emergency: A review of the 2019 novel coronavirus (COVID-19). International Journal of Surgery, 2, $71-76$.

[18] Sugiyono. (2013). Metode penelitian Manajemen. Alfabeta.

[19] Sugiyono. (2015). Metode Penelitian \& Pengembangan Research and Development. Alfabeta. 
[20] Pratiwi, A. E. (2016). Analisis Pasar Wisata Sayiah Di Kota Yogyakarta. Analisis Pasar Wisata Sayiah Di Kota Yogyakarta, 14(Mei), 345-364.

[21] Syahriza, R. (2014). Pariwisata Berbasis Syariah ( Telaah Makna Kata Sara dan Derivasinya dalam alQur' an ). Human Falah: Jurnal Ekonomi Dan Bisnis Islam, 1(2), 135-145.

[22] Duman, T. (2011). Value of Islamic tourism offering: Perspectives from the Turkish experience. World Islamic Tourism Forum (WITF, 2011), Kuala ..., July, 1-18.

[23] Irawan, E. (2015). Implementasi Kebijakan Pembangunan Pariwisata di Kabupaten Banyuwangi. JJurnal Ejaring Administrasi Publik, 7(2), 757-770.

[24] Mishra, P. K., Rout, H. B., \& Mohapatra, S. S. (2011). Causality between tourism and economic growth: Empirical evidence from India. European Journal of Social Sciences, 18(4), 518-527.

[25] Suni, M., \& Badollahi, M. Z. (2019). Pengembangan Sumber Daya Manusia di Bidang Pariwisata: Perspektif Potensi Wisata Daerah Kabupaten Barru, Sulawesi-Selatan. Jurnal Kepariwisataan Dan Hospitalitas, 3(November), 109-119.

Pendapatan dan Kesejahteraan Masyarakat. Muslim Heritage, 3(1), 157. https://doi.org/10.21154/muslimheritage.v3i1.1303

Covid19.go.id. (2020). Peta Sebaran.

BNBP. (2020). Laporan Media Harian COVID-19 Tanggal 1 Mei 2020 Pukul 12.00.

BPS. (2020). Perkembangan Kunjungan Wisatawan Mancanegara Ke Indonesia Tahun 2020 vs 2018.

KataData. (2018). Pendapatan Devisa Indonesia dair Sektor Pariwisata (2009-2019E).

KataData. (2019a). Jumlah Kunjungan Wisman ke Indonesia 2009-2018.

KataData. (2019b). Jumlah Perjalanan dan Pengeluaran Wisatawan Nusantara (2012-2018).

KataData. (2020). Cadangan Devisa Indonesia. 